JURNAL CEMERLANG: Pengabdian pada Masyarakat ISSN 2654-4741

Vol. 1, No. 1, 2018, $37-57$

DOI: https://doi.org/10.31540/jpm.v1i1.140

\title{
OPTIMALISASI PELAYANAN PAUD HOLISTIK MELALUI PELATIHAN KADER DI DESA LEMAH MULYA KECAMATAN MAJALAYA KABUPATEN \\ KARAWANG
}

Nelly Apriningrum, Maria Alia Rahayu

Universitas Singaperbangsa Karawang, Indonesia

\begin{abstract}
ABSTRAK
Pelayanan posyandu di Desa Lemah mulya sebagai unit kesehatan berbasis masyarakat yang ada selama ini masih berfokus pada pelayanan penimbangan berat badan, pemberian vitamin A dan pemberian imunisasi serta cenderung mengabaikan pemantauan perkembangan balita. Upaya pemerintah mengatasi permasalahan tersebut dengan memadukan program PAUD, posyandu dan BKB melalui Optimalisasi pelayanan PAUD Holistik yang bertujuan agar setiap balita mendapatkan pelayanan secara menyeluruh sesuai kebutuhan. Metode pelaksanaan kegiatan ini adalah dengan memberikan pelatihan kepada para guru PAUD, kader posyandu dan BKB melalui pendekatan partispatif dari masyarakat. Hasil dari kegiatan pengabdian ini berupa terjalinnya kerjasama antar kader melalui pelayanan integrasi, peningkatan pengetahuan kader tentang pertumbuhan dan perkembangan balita, investasi SDIDTK kit serta implementasi Optimalisasi PAUD holistik di Desa Lemah mulya. Potensi tokoh masyarakat, kader dan warga masyarakat menjadi peluang terlaksananya kegiatan PAUD Holistik serta diharapkan dapat dilaksanakan secara berkelanjutan.
\end{abstract}

\section{KEYWORDS}

Holistik, PAUD, deteksi, penyimpangan, pertumbuhan, perkembangan, balita
ARTICLE HISTORY

Received 3 November 2018

Revised 25 November 2018

Accepted 5 December 2018

CORRESPONDENCE Nelly Apriningrum@nelly.apriningrum@fkes.unsika.ac.id

\section{PENDAHULUAN}

Pembangunan kesehatan salah satunya diselenggarakan sebagai upaya meningkatan kesehatananak sejak masih didalam kandungan hingga lima tahun pertama kehidupannya. Sebagai generasi penerus bangsa, masa balita perlu mendapat perhatian yang cukup serius, diantaranya dengan memfasilitasi lingkungan yang mendukung serta memberikan stimulasi, deteksi, dan intervensi 


\section{JURNAL CEMERLANG: Pengabdian pada Masyarakat}

ISSN 2654-4741

Vol. 1, No. 1, 2018, $37-57$

DOI: https://doi.org/10.31540/jpm.v1i1.140

dini tumbung kembang (SDIDTK) pada anak (Kemenkes RI, 2016).Selama ini kegiatan pelayanan posyandu balita di Desa Lemahmulya Kecamatan Majalaya masih belum menyentuh aspek pemantauan tumbuh kembang secara komprehensif, masih terfokus hanya pada pemantauan pertumbuhan dan kurang memperhatikan perkembangan, sedangkan kebutuhan balita sebagai periode emas mencakup pertumbuhan, perkembangan baik motorik kasar, motorik halus, bahasa maupun kemandirian sosial demikian juga kebutuhan gizi. Tujuan dilakukannya pengabdian kepada masyarakat ini diharapkan dapat menjalin kerjasama untuk mengoptimalkan potensi yang ada dimasyarakat melalui "Pembinaan PAUD Holistik di Desa Lemahmulya Kecamatan Majalaya Kabupaten Karawang" sebagai manifestasi pelayanan unit kesehatan berbasis masyarakat yang terdapat didesa.

Permasalahan yang ada di Desa Lemahmulya tersebut perlu solusi dengan bekerjasama melalui mitra kelompok posyandu dan PAUD (Pendidikan Anak Usia Dini) melalui optimalisasi PAUD holistik. Problem solving dari permasalahan yang muncul dengan memberikan pelatihan, refreshing serta pemberdayaan masyarakat diantaranya dengan pembentukan kaderisasi yang terdiri dari para kader meliputi guru PAUD, kader kesehatan, serta membentuk kader kelompok Bina Keluarga Balita (BKB) untuk dapat mengoptimalkan pelayanan pendidikan dan kesehatan yang ada dimasyarakat. Identifikasi permasalahan yang didapatkan adalah pelayanan posyandu yang berfokus hanya pada pertumbuhan, belum adanya kerjasama antara posyandu dengan lembaga PAUD terdekat, rendahnya pengetahuan dan keterampilan guru PAUD dan kader tentang SDIDTK, belum adanya sarana maupun alat untuk pemantauan dan deteksi adanya penyimpangan pada tumbuh kembang anak.

Berdasarkan hasil studi pendahuluan dan studi pustaka menggambarkan bahwa posyandu sebagai unit pelayanan dasar berbasis masyarakat untuk memenuhi kebutuhan dasar pengembangan kualitas manusia sejak dini, juga sebagai komponen dalam perwujudan kesejahteraan keluarga.Sebagai salah satu bentuk Upaya Kesehatan Berbasis Masyarakat (UKBM) yang dikelola dan 


\section{JURNAL CEMERLANG: Pengabdian pada Masyarakat}

ISSN 2654-4741

Vol. 1, No. 1, 2018, $37-57$

DOI: https://doi.org/10.31540/jpm.v1i1.140

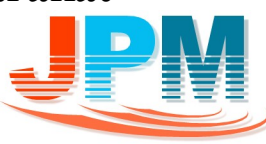

diselenggarakan dari, oleh, untuk dan bersama masyarakat dalam penyelenggaraan pelayanan dan pembangunan kesehatan untuk memberikan kemudahan masyarakat dalam memperoleh pelayanan kesehatan dasar serta menurunkan angka kesakitan dan kematian ibu dan bayi. Oleh karena itu, upaya revitalisasi posyandu perlu terus ditingkatkan agar bisa memenuhi kebutuhan tumbuh kembang anak sejak dalam kandungan dan mampu meningkatkan dan mempertahankan status gizi serta derajat kesehatan ibu dan anak. Secara terperinci revitalisasi mempunyai tujuan sebagai berikut : (1) Meningkatkan kualitas kemampuan dan keterampilan kader posyandu. (2) Meningkatkan pengelolaan dalam pelayanan posyandu. (3) Meningkatkan pemenuhan kelengkapan sarana, alat dan obat di posyandu. (4) meningkatkan kemitraan dan pemberdayaan masyarakat untuk kesinambungan kegiatan posyandu. (5) Meningkatkan fungsi pendampingan dan kualitas pembinaan posyandu(Kemenkes RI, 2011 dan Sukesi, 2011).

Program dalam pelayanan PAUD dan posyandu memiliki persamaan misi untuk mensejahterakan masyarakat termasuk kelompok rentan yaitu bayi dan balita. Permasalahan yang ada dapat diselesaikan dengan mengoptimalkan kegiatan pelayanan PAUD dan posyandu, dengan demikian upaya untuk mengatasi permasalahan di desa Lemahmulya adalah dengan melakukan pengabdian kepada masyarakat untuk mengoptimalkan PAUD Holistik di desa Lemahmulya Kecamatan Majalaya Kabupaten Karawang. Tujuan kegiatan ini untuk mengoptimalkan kegiatan pelayanan PAUD secara holistik, dengan melakukan pendekatan kepada pemangku kebijakan setempat untuk mendapatkan izin dan dukungan rencana kegiatan, membentuk kelompok Bina Keluarga Balita (BKB), memberikan pelatihan dan refreshing bagi para kader serta mengoptimalkan pelayanan PAUD dan posyandu serta BKB secara menyeluruh dan terintegrasi.

\section{MASALAH}

https://ojs.stkippgri-lubuklinggau.ac.id/index.php/JPM 


\section{JURNAL CEMERLANG: Pengabdian pada Masyarakat}

ISSN 2654-4741

Vol. 1, No. 1, 2018, $37-57$

DOI: https://doi.org/10.31540/jpm.v1i1.140

Berdasarkan latarbelakang permasalahan dan analisis situasi, perumusan masalah pada kegiatan pengabdian ini meliputi :

1. Pelayanan posyandu masih terfokus hanya pada pemantauan pertumbuhan saja belum mengarah padapemantauan perkembangan.

2. Belum adasertabelumoptimalnyakerjasama antara posyandu dengan PAUD

3. Keterbatasan waktu bagi tenaga kesehatan dalam pelayanan posyandu.

4. Belum optimalnya kader BKB dalam pelaksanaan PAUD holistik.

5. Kurangnya pengetahuan dan keterampilan kaderposyandu, kader BKBserta guru PAUD tentang SDIDTK.

6. Belum adanya SDIDTK kit balitausia $<2$ tahundalampelayananposyandu sertadi PAUDImandiri.

\section{METODE}

Pelaksanaankegiatan pengabdian masyarakat ini difokuskan pada kegiatan pelatihan dan pelayanan PAUD holistik di desa Lemahmulya dengan uraian kegiatan sebagai berikut :

\section{Tahap Persiapan}

Pada tahap ini diawali denganmeminta izin kepada kepala desa dan kepala puskesmas setempat dalam rangka pelaksanaan kegiatan pengabdian, menyampaikan tujuan serta permohonan dukungan. Selanjutnya penyampaian maksud dan tujuan kepada pihak terkait yang terdiri dari kepala sekolah PAUD, bidan desa serta para kader. Selain itu kegiatan ini juga melibatkan 10 mahasiswa kebidanan untuk dapat mengaplikasikan teori yang didapat dikampus kepada masyarakat. Hasil dari tahapan persiapan berupa diperkenankannya tim pengabdi untuk menyampaikan rencana kegiatan kepada masyarakat secara keseluruhan melalui kegiatan minggon desa, serta pemilihan kader kegiatan pengabdian dari unsur masyarakat. Pertemuan kader dan tim pengabdian diawali dengan self assesment untuk menyamakan persepsi permasalahan yang ada di masyarakat, serta alternatif solusi

https://ojs.stkippgri-lubuklinggau.ac.id/index.php/JPM 


\section{JURNAL CEMERLANG: Pengabdian pada Masyarakat}

ISSN 2654-4741

Vol. 1, No. 1, 2018, $37-57$

DOI: https://doi.org/10.31540/jpm.v1i1.140

\section{Tahap Pelaksanaan}

Pelaksanaan pada kegiatan pengabdian ini menggunakan pendekatan penyelesaian masalah berdasarkan kesepakatan antara tim pengabdian dengan mitra melalui pendekatan partispatif, yang meliputi : Metode diskusi/ konsultasi untuk mengkoordinasikan pelayanan posyandu dengan PAUD agar terjalin kerjasama pelayanan integrasi, pemilihan dan pembentukan kader BKB (Bina Keluarga Balita).

Metode lokakarya dengan memberikan pelatihan dan refreshing bagi para kader BKB, posyandu dan PAUD. Selanjutnya dalam kegiatan praktikum dengan memfasilitasi terlebih dahulu sarana pelayanan PAUD Holistik dengan investasi SDIDTK kit.

Setelah pemberian materi baik teori maupun praktik, serta investasi alat SDIDTK, maka dilakukan metode perencanaan untuk mengimplementasikan pelayanan posyandu yang diintegrasikan dengan layanan PAUD dan BKB sesuai dengan tugas dan tanggungjawabnya.

\section{Tahap Monitoring Evaluasi}

Kegiatan pelaksanaan pengabdian dengan mengoptimalkan pelayanan PAUD yang diintegrasikan dengan pelayanan posyandu serta pembentukan BKB sebagaian bagian dari komponen yang diperlukan untuk mewujudkan kegiatan yang dilaksananakan setiap bulannya. Tahap ini merupakan tahap implementasi dari beberapa metode yang sudah direncanakan dan dipersiapkan. Melalui tahapan ini juga dapat dilakukan evaluasi dan monitoring dari apa yang telah dilakukan sebelumnya mulai dari persiapan, perencanaan dan pelaksanaan dengan beberapa metode. Hal ini juga dilakukan untuk mempersiapkan bahwa kegiatan selama pengabdian dapat dilaksanakan secara berkelanjutan.

\section{Teknik Pengumpulan data}

Pengumpulan data pada kegiatan pengabdian masyarakat ini dengan memberdayakan para kader untuk mendapatkan data akurat jumlah balita di desa lemahmulya dan bekerjasama dengan bidan desa setempat serta guru PAUD. 
JURNAL CEMERLANG: Pengabdian pada Masyarakat ISSN 2654-4741

Vol. 1, No. 1, 2018, 37 - 57

DOI: https://doi.org/10.31540/jpm.v1i1.140

Pengumpulan data pengetahuan dan keterampilan para kader tentang pertumbuhan dan perkembangan dilakukan dengan menggunakan kuesioner

\section{Teknik Analisis Data}

Data yang terkumpulkan dianalisis dengan menggunakan metode kuantitatif sehingga didapatkan distribusi frekuensi tentang pengetahuan pertumbuhan dan perkembangan balita.

\section{Lokasi, waktu, dan durasi kegiatan}

Kegiatan pengabdian masyarakat ini dilakukan di Desa Lemahmulya Kecamatan Majalaya Kabupaten KARAWANG khususnya pada PAUD Imandiri dan Posyandu Cempaka VI. Rincian kegiatan pelatihan diuraikan dalam tabel pelaksanaan kegiatan berikut :

Tabel 1. Kegiatan Pelaksanaan Kegiatan Pengabdian Masyarakat.

\begin{tabular}{|c|c|c|c|c|}
\hline No & Kegiatan & Narasumber & Waktu & $\begin{array}{ll}\text { Tujuan } & \text { dan } \\
\text { Pelaksanaan } & \end{array}$ \\
\hline 1. & $\begin{array}{l}\text { Menjalin } \\
\text { kerjasama } \\
\text { dengan mitra }\end{array}$ & $\begin{array}{l}\text { H. Cecep W } \\
\text { Khaerudin, } \\
\text { SPd } \\
\text { Nelly A, } \\
\text { M.Keb }\end{array}$ & $\begin{array}{l}2 \times 1 \text { jam } \\
09-07-18\end{array}$ & $\begin{array}{lr}\text { Sosialisasi } & \text { kegiatan } \\
\text { program dengan pihak } \\
\text { terkait } \\
\text { Terbentuknya } \\
\text { kerjasama dengan mitra } \\
\text { melalui } \\
\text { permohonan } \\
\text { pelaksanaan kegiatan } \\
\text { Pembentukan } \\
\text { struktur } \\
\text { Kelompok } \\
\text { Melalui Surganigram } \\
\text { Desa No : } \\
\text { DS/ } 2018 \text { KKB }\end{array}$ \\
\hline \multicolumn{5}{|c|}{ Pelatihan SDIDTK untuk Guru PAUD Dan Kader Posyandu dan BKB } \\
\hline No & $\begin{array}{l}\text { MateriPelatih } \\
\text { an }\end{array}$ & & Waktu & $\begin{array}{l}\text { Tujuan } \\
\text { Pelaksanaan }\end{array}$ \\
\hline 2. & $\begin{array}{l}\text { Konseppertum } \\
\text { buhan dan } \\
\text { perkembangan }\end{array}$ & $\begin{array}{l}\text { Nelly A, } \\
\text { M.Keb }\end{array}$ & $\begin{array}{l}2 \times 4 \text { jam } \\
10-08-18\end{array}$ & $\begin{array}{lr}\text { Memahami } & \text { konsep } \\
\text { pertumbuhan } & \text { dan } \\
\text { perkembangan } & \text { bayi, }\end{array}$ \\
\hline
\end{tabular}

https://ojs.stkippgri-lubuklinggau.ac.id/index.php/JPM 
JURNAL CEMERLANG: Pengabdian pada Masyarakat ISSN 2654-4741

Vol. 1, No. 1, 2018, $37-57$

DOI: https://doi.org/10.31540/jpm.v1i1.140

\begin{tabular}{|c|c|c|c|c|}
\hline & & $\begin{array}{c}\text { Maria A, } \\
\text { M.KM }\end{array}$ & & $\begin{array}{l}\text { balita dan anak } \\
\text { prasekolah. } \\
\text { Memahami ciri dan } \\
\text { prinsip tumbuh } \\
\text { kembang anak } \\
\text { Memahami faktor yang } \\
\text { mempengaruhi kualitas } \\
\text { tumbuh kembang } \\
\text { Memahami aspek } \\
\text { perkembangan yang } \\
\text { perlu dipantau } \\
\text { Memahami periode } \\
\text { tumbuhkembang anak. } \\
\text { Memahami beberapa } \\
\text { gangguan } \\
\text { tumbuhkembang yang } \\
\text { sering ditemukan }\end{array}$ \\
\hline 3. & $\begin{array}{l}\text { Pemantauanpe } \\
\text { rtumbuhanbayi } \\
\text {, balitadan } \\
\text { anakprasekola } \\
\text { h }\end{array}$ & $\begin{array}{l}\text { Nelly A } \\
\text { Maria A, } \\
\text { M.KM }\end{array}$ & $\begin{array}{l}2 \times 3 \text { jam } \\
15-08-18\end{array}$ & $\begin{array}{l}\text { Mengidentifikasi } \\
\text { pertumbuhan bayi, } \\
\text { balita dan anak } \\
\text { prasekolah } \\
\text { Mengidentifikasi } \\
\text { pertumbuhan bayi, } \\
\text { balita melalui KMS } \\
\text { Mengelola pelayanan } \\
\text { pertumbuhanbayi, } \\
\text { balita berdasarkan } \\
\text { KMS serta } \\
\text { mengidentifikasi status } \\
\text { gizi }\end{array}$ \\
\hline 4. & $\begin{array}{l}\text { Stimulasitumb } \\
\text { uhkembangbal } \\
\text { ita dan } \\
\text { anakprasekola } \\
\text { h }\end{array}$ & $\begin{array}{l}\text { Meliaswati, } \\
\text { Amd } \\
\text { Ine N, M.Pd } \\
\text { Endah K, } \\
\text { S.Pd }\end{array}$ & $\begin{array}{l}2 \times 4 \text { jam } \\
31-09-18\end{array}$ & $\begin{array}{l}\text { Memahami cara } \\
\text { memberikan stimulasi } \\
\text { tumbuhkembang pada } \\
\text { masa bayi, balita dan } \\
\text { anak prasekolah, } \\
\text { meliputi : } \\
\text { Gerak kasar } \\
\text { Gerak halus } \\
\text { Kemampuan bicara dan } \\
\text { bahasa } \\
\text { Kemampuan } \\
\text { kemandirian }\end{array}$ \\
\hline
\end{tabular}

https://ojs.stkippgri-lubuklinggau.ac.id/index.php/JPM 
JURNAL CEMERLANG: Pengabdian pada Masyarakat ISSN 2654-4741

Vol. 1, No. 1, 2018, $37-57$

DOI: https://doi.org/10.31540/jpm.v1i1.140

\begin{tabular}{|c|c|c|c|c|}
\hline 5. & $\begin{array}{l}\text { Deteksitumbu } \\
\text { hkembanganak }\end{array}$ & $\begin{array}{l}\text { Meliaswati, } \\
\text { Amd } \\
\text { Ine N, M. , Pd }\end{array}$ & $\begin{array}{l}2 \times 4 \text { jam } \\
01-09-18\end{array}$ & $\begin{array}{lr}\text { Deteksi } & \text { dini } \\
\text { penyimpangan } & \\
\text { pertumbuhan } & \\
\text { Deteksi } & \text { dini } \\
\text { penyimpangan } & \\
\text { perkembangan; KPSP, } \\
\text { TDD/TDL }\end{array}$ \\
\hline 6. & $\begin{array}{l}\text { Intervensi dan } \\
\text { rujukan dini, } \\
\text { penyimpangan } \\
\text { perkembangan } \\
\text { anak }\end{array}$ & $\begin{array}{l}\text { Nelly } \\
\text { AM.Keb } \\
\text { Maria A, } \\
\text { M.Keb }\end{array}$ & $\begin{array}{l}2 \times 2 \text { jam } \\
09-09-18\end{array}$ & $\begin{array}{ll}\text { Intervensi } & \text { dini } \\
\text { penyimpangan } & \\
\text { perkembangan } & \\
\text { Intervensi } & \\
\text { perkembangan } & \\
\text { Evaluasi intervensi } \\
\text { perkembangan } \\
\text { Rujukan } \\
\text { penyimpangan dini } \\
\text { perkembangan pada } \\
\text { tingkat keluarga dan } \\
\text { masyarakat }\end{array}$ \\
\hline 7. & $\begin{array}{l}\text { Praktikum } \\
\text { stimulasi } \\
\text { tumbuhkemba } \\
\text { ng }\end{array}$ & $\begin{array}{l}\text { IneN, M.Pd } \\
\text { Nelly A, } \\
\text { M.Keb } \\
\text { Uway Wariah, } \\
\text { M.Kes }\end{array}$ & $\begin{array}{l}2 \times 3 \text { jam } \\
10-09-18\end{array}$ & $\begin{array}{l}\text { Praktikum cara } \\
\text { memberikan stimulasi } \\
\text { tumbuhkembang pada } \\
\text { masa bayi, balita dan } \\
\text { anak prasekolah, } \\
\text { meliputi : } \\
\text { Gerak kasar } \\
\text { Gerak halus } \\
\text { Kemampuan bicara dan } \\
\text { Bahasa } \\
\text { Kemampuan } \\
\text { kemandirian }\end{array}$ \\
\hline 8. & $\begin{array}{l}\text { Praktikum } \\
\text { deteksi } \\
\text { tumbuhkemba } \\
\text { ng }\end{array}$ & $\begin{array}{l}\text { Ine N, M.Pd } \\
\text { Nelly A, } \\
\text { M.Keb }\end{array}$ & $\begin{array}{l}2 \times 3 \text { jam } \\
11-09-18\end{array}$ & $\begin{array}{ll}\text { Praktikum deteksi } & \text { dini } \\
\text { penyimpangan } & \\
\text { pertumbuhan } & \\
\text { Deteksi } & \text { dini } \\
\text { penyimpangan } & \\
\text { perkembangan } & \end{array}$ \\
\hline \multicolumn{2}{|c|}{ Jumlah jam } & & \multicolumn{2}{|l|}{48 Jam } \\
\hline
\end{tabular}


JURNAL CEMERLANG: Pengabdian pada Masyarakat ISSN 2654-4741

Vol. 1, No. 1, 2018, $37-57$

DOI: https://doi.org/10.31540/jpm.v1i1.140

Kegiatan pengabdian masyarakat dengan skema program kemitraan masyarakat di Desa Lemahmulya Kecamatan Majalaya Kabupaten Karawang telah terlaksana, beberapa kegiatan yang dilaksanakan diantaranya adalah sebagai berikut :

\section{Self assesment lapangan}

Hasil dari self asessment di desa lemahmulya didapatkan bahwa pelayanan posyandu sebagai unit kesehatan berbasis masyarakat, masih berfokus pada pelayanan imunisasi, pemberian vitamin A serta pemantauan pertumbuhan dan terkesan mengabaikan pemantauan dan pelayanan perkembangan bayi dan balita. Keterbatasan waktu dan overload tugas dari bidan desa sebagai tenaga kesehatan yang dekat dengan masyarakat menjadi salah satu penyebab dari permasalahan yang ada. Adanya lembaga Pendidikan Anak Usia Dini yang ada di wilayah setempat belum dapat diberdayakan secara optimal untuk mengatasi permasalahan tersebut. Keterbatasan pengetahuan kader posyandu tentang materi pengetahuan dan perkembangan bayi balita juga menjadi salah satu pendukung belum dapat dilaksanakannya pelayanan PAUD holistik. Hasil dari self asessment dengan melakukan pemilihan tim untuk pelaksanaan kegiatan pengabdian dari unsur perangkat desa dan masyarakat. Dukungan dari pemangku kebijakan dan tokoh masyarakat serta pemberdayan dari masyarakat menjadi penentu terlaksananya kegiatan pengabdian ini.

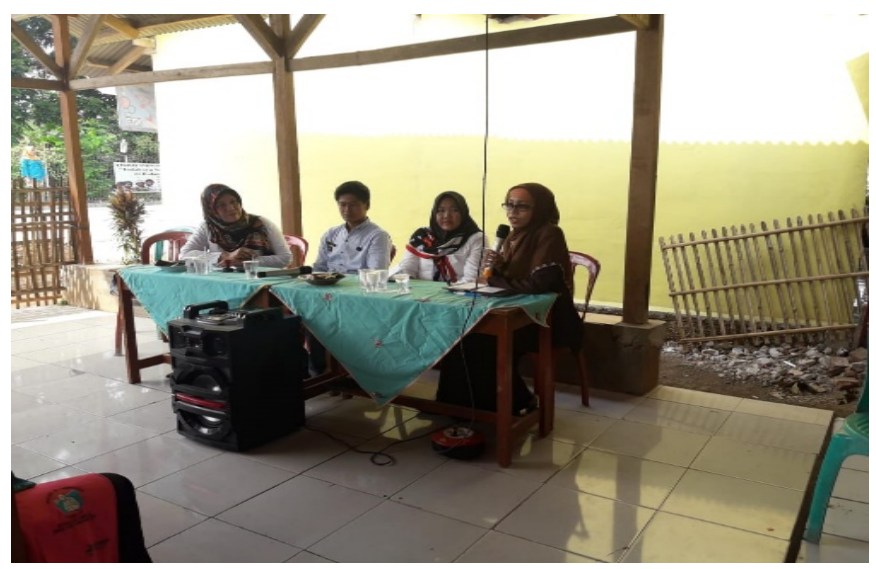

Gambar 1. Kegiatan pelaksanaan pengabdian, pendekatan kepada pemangku kebijakaan serta persamaan persepsi dan self asessment lapangan

https://ojs.stkippgri-lubuklinggau.ac.id/index.php/JPM 
JURNAL CEMERLANG: Pengabdian pada Masyarakat ISSN 2654-4741

Vol. 1, No. 1, 2018, $37-57$

DOI: https://doi.org/10.31540/jpm.v1i1.140

\section{Pembentukan tim BKB}

Kegiatan pelayanan posyandu yang masih terpisah dengan pelayanan PAUD menjadi bagian dari permasalahan yang ada. Selain itu belum adanya kader BKB dan belum optimalnya pelayanan BKB yang terintegrasi dengan pelayanan PAUD dan posyandu juga menjadi permasalahan untuk dicarikan solusi melalui pembentukan tim BKB melalui SK kepala desa setempat.

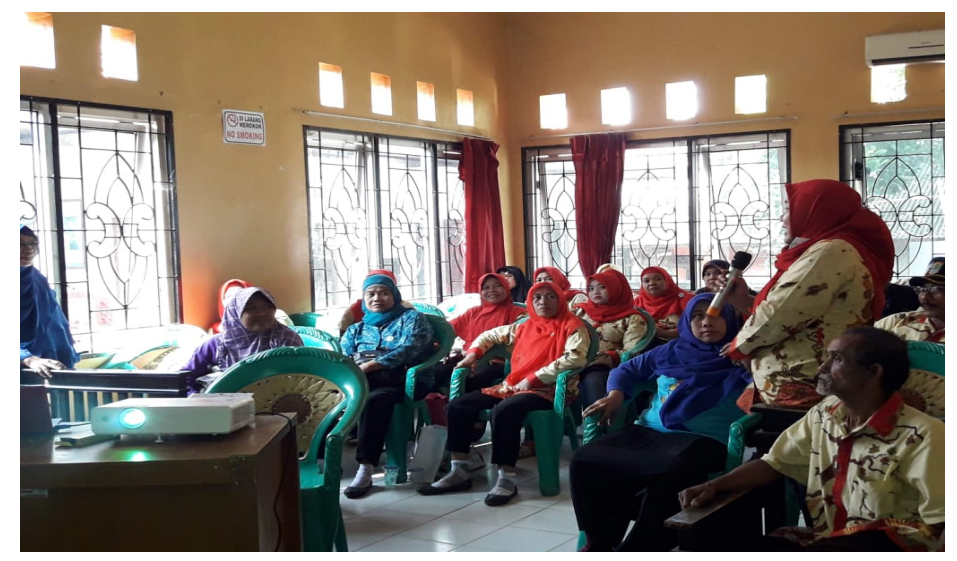

Gambar 2. Kegiatan pemilihan dan pembentukan tim BKB

Pelaksanaan Refereshing/ pelatihan bagi kader posyandu, guru PAUD dan

\section{kader BKB}

Alternatif solusi yang ditawarkan dari permasalahan yang ada dengan memberikan pelatihan, refreshing bagi para kader, materi yang diberikan meliputi teori dan praktikum mengenai :

1. BKB

Merupakan salah satu kegiatan atau wadah kegiatan keluarga yang mempunyai anak berumur dibawah lima tahun (balita). Para ahli mengatakan bahwa masa balita disebut sebagai masa emas (golden age period). Apabila pada masa tersebut anak balita tidak dibina dengan baik, maka anak tersebut akan mengalami gangguan perkembangan emosi, sosial, mental, intelektual, dan moral yang akan sangat menentukan sikap serta nilai perilakunya di kemudian hari. Kegiatan BKB ini mengusahakan sedini mungkin pembinaan tumbuh kembang anak balita sesuai dengan usia dan tahap perkembangan yang harus dimiliki, baik dalam aspek fisik, kecerdasan, emosional maupun https://ojs.stkippgri-lubuklinggau.ac.id/index.php/JPM 


\section{JURNAL CEMERLANG: Pengabdian pada Masyarakat}

ISSN 2654-4741

Vol. 1, No. 1, 2018, $37-57$

DOI: https://doi.org/10.31540/jpm.v1i1.140

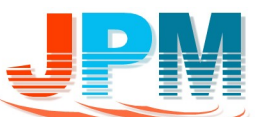

sosial, agar dapat tumbuh dan berkembang menjadi anak yang maju mandiri dan berkualitas.Melalui kegiatan BKB diharapkan setiap keluarga akan mampu membina anak-anak balitanya dan anak prasekolah sehingga tumbuh dan berkembang secara optimal, berkepribadian luhur, cerdas, serta taqwa kepada Tuhan Yang Maha Esa(Suprapto, 2012)

Program BKB bertujuan untuk meningkatkan pengetahuan dan keterampilan orang tua dan anggota keluarga lainnya dalam membina tumbuh kembang balita melalui rangsangan fisik, motorik, kecerdasan, emosional, dan sosial ekonomi dengn sebaik-baiknya. Dengan bekal pengetahuan dan keterampilan tersebut diharapkan orang tua mampu mendidik dan mengasuh anak balitanya sejak dini agar dapat tumbuh dan berkembang menjadi manusia Indonesia yang berkualitas. Dengan mengikuti kegiatan BKB orang tua akan lebih memahami perkembangan dan ciri-ciri khas pada usia tertentu serta mengetahui cara dan dapat melakukan pembinaan agar anak tumbuh dan berkembang secara optimal.

Kegiatan pokok BKB meliputi sosialisasi peran keluarga, bimbingan dan konsultasi, pemberdayaan dan peningkatan peran perempuan dan keluarga muda mandiri (KMM). Parenting skills juga dilakukan agara keluarga memahami dan mampu melakukan perawatan, pengasuhan, pengasahan dan perlindungan terhadap anak. Faktor pembeda program BKB dengan program anak usia dini yang lain antara lain adalah : (1) program BKB menitikberatkan pada pembinaan orang tua dan anggota keluarga lainnya yang memiliki balita. (2) membina tumbuh kembang anak balita (3) menggunakan alat bantu dalam hubungan timbal balik antara orang tua dan anak berupa alat permainan antara lain alat permainan edukatif (APE), cerita, dongeng, nyanyian sebagai perangsang tumbuh kembang anak. (4) menitikberatkan perlakuan orang tua yang tidak membedakan anak laki-laki serta perempuan. Kegiatan BKB bisa dilaksanakan sebulan sekali selama 2 jam/kunjungan. Mengingat sebagian besar waktu anak dihabiskan bersama ibunya, maka pemberian pendidikan bagi ibu sebagaimana diberikan melalui 
JURNAL CEMERLANG: Pengabdian pada Masyarakat

ISSN 2654-4741

Vol. 1, No. 1, 2018, 37 - 57

DOI: https://doi.org/10.31540/jpm.v1i1.140

posyandu dan BKB memberikan manfaat sangat besar dalam menerapkan pola asuh pada anak usia dini secara benar.

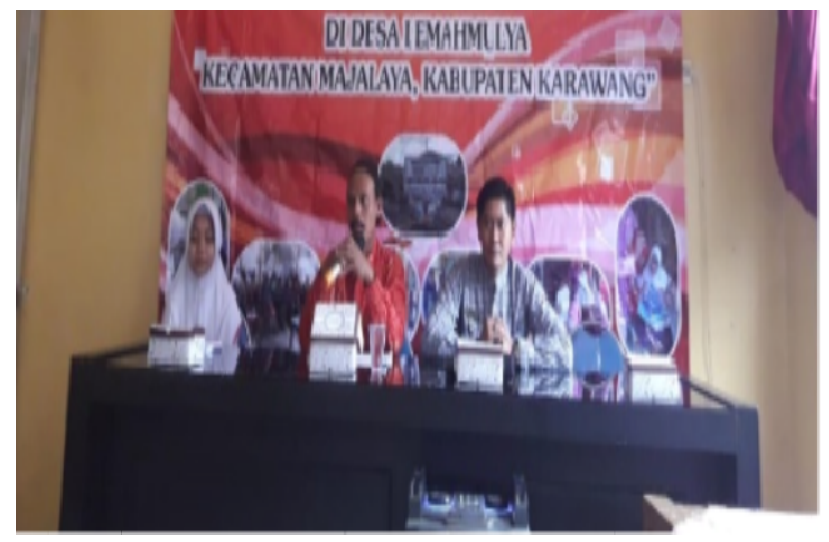

\section{Gambar 3. Pemaparan tentang BKB dari Kecamatan}

2. Posyandu

Posyandu sebagai unit pelayanan dasar masyarakat,secara langsung memenuhi kebutuhan dasar pengembangan kualitas manusia sejak dini, sekaligus merupakan salah satu komponen perwujudan kesejahteraan keluarga. Agar posyandu dapat melaksanakan fungsi dasarnya maka perlu upaya revitalisasi terhadap fungsi dan kinerja posyandu. Upaya tersebut sudah dipaksakan tetapi masih belum menunjukan hasil yang optimal. Oleh karena itu, upaya optimalisasi posyandu perlu terus ditingkatkan agar bisa memenuhi kebutuhan tumbuh kembang anak sejak dalam kandungan dan mampu meningkan atau mempertahankan status gizi serta derajat kesehatan ibu dan anak (Nurul, 2010).

Secara terperinci optimalisasi posyandu mempunyai tujuan sebagai berikut : (1) Meningkatkan kualitas kemampuan dan keterampilan kader posyandu. (2) Meningkatkan pengelolaan dalam pelayanan posyandu. (3) Meningkatkan pemenuhan kelengkapan sarana, alat dan obat di posyandu. (4) meningkatkan kemitraan dan pemberdayaan masyarakat untuk kesinambungan kegiatan posyandu. (5) Meningkatkan fungsi pendampingan dan kualitas pembinaan posyandu. 
JURNAL CEMERLANG: Pengabdian pada Masyarakat ISSN 2654-4741

Vol. 1, No. 1, 2018, $37-57$

DOI: https://doi.org/10.31540/jpm.v1i1.140

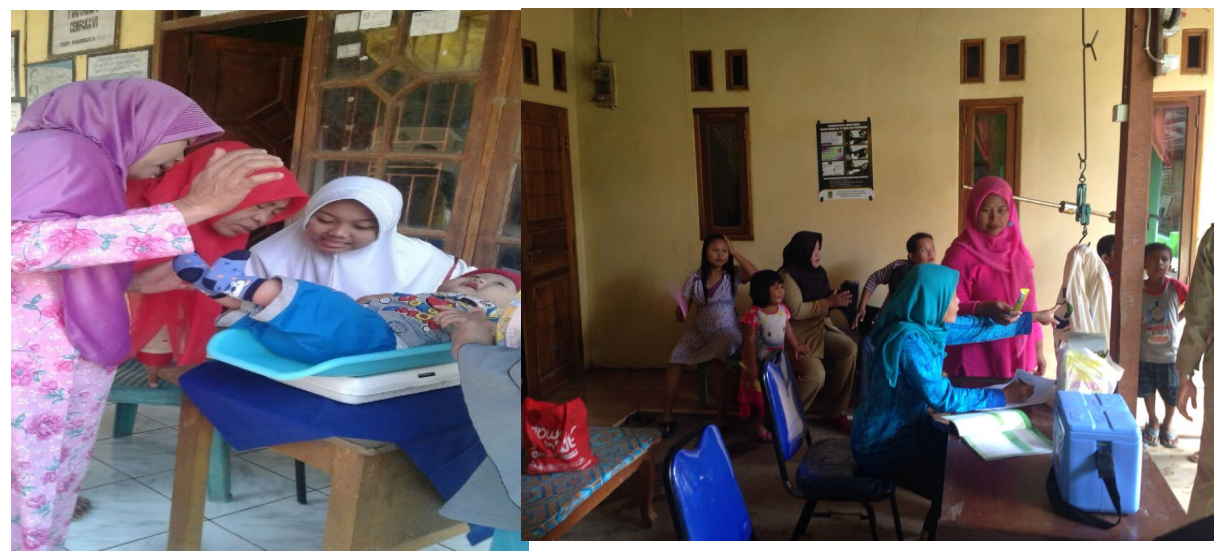

Gambar 4. Pelaksanaan Kegiatan Posyandu

3. Konsep pertumbuhan

Konsep tentang pertumbuhan sebagai tahapan yang akan dilewati oleh balita, juga dibahas kembali dalam kegiatan refreshing. Pertumbuhan merupakan bertambahnya sebagian atau seluruh ukuran fisik dan struktur tubuh, memiliki beberapa ciri dan prinsip serta beberapa faktor yang mempengaruhinya. Kader BKB dan posyandu harus mengetahui perbedaan pertumbuhan dan perkembangan, yang selanjutnya dapat melakukan pemantauan pertumbuhan bayi balita. Pemantauan pertumbuhan yang selama ini dilakukan dengan melakukan pengukuran berat badan, maka pada pelatihan diberikan materi pengukuran lingkar lengan atas agar mengetahui status gizi serta pengukuran lingkar kepala.

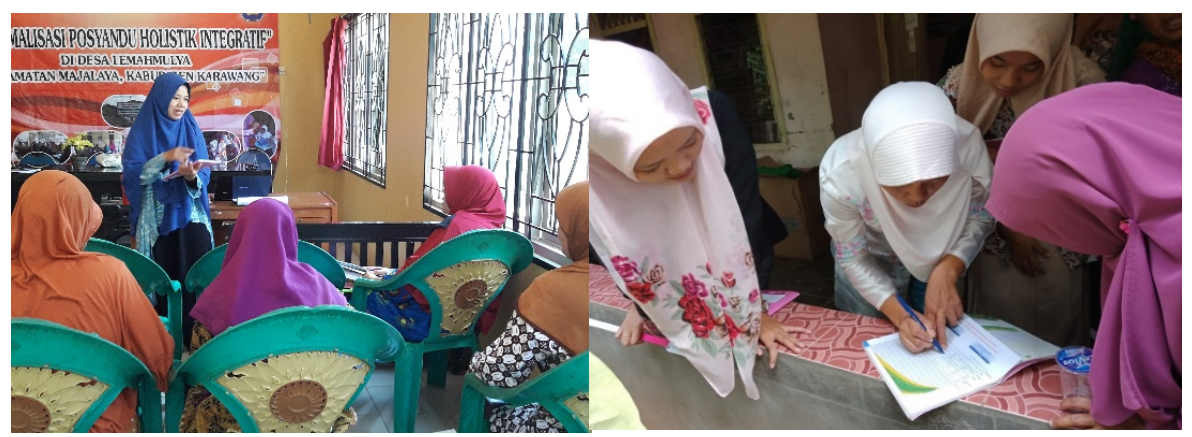

Gambar 5. Konsep Pertumbuhan, Pengisian Kelengkapan KMS dan Status Gizi Balita 
JURNAL CEMERLANG: Pengabdian pada Masyarakat ISSN 2654-4741

Vol. 1, No. 1, 2018, $37-57$

DOI: https://doi.org/10.31540/jpm.vli1.140

4. Konsep perkembangan

Selain konsep pertumbuhan, konsep perkembangan menjadi fokus dalam kegiatan refreshing dan pelatihan ini, mengingat terbatasnya pemantauan perkembangan. Definisi perkembangan yang merupakan bertambahnya struktur dan fungsi tubuh yang lebih kompleks dalam kemampuan gerak kasar, gerak halus, bicara, bahasa dan sosialisasi serta kemandirian. Ciri-ciri dan prinsip perkembangan serta faktor yang mempengaruhinya.

Pada pelatihan diberikan materi beberapa aspek perkembangan yang harus dipantau serta periode atau tahapan perkembangan dan pemantauannya. Selain konsep dan praktik pematauan dan stimulasi perkembangan balita, pada kegiatan pengabdian ini juga diberikan stimulan berupa investasi alat SDIDTK untuk menunjang pemantauan perkembangan.

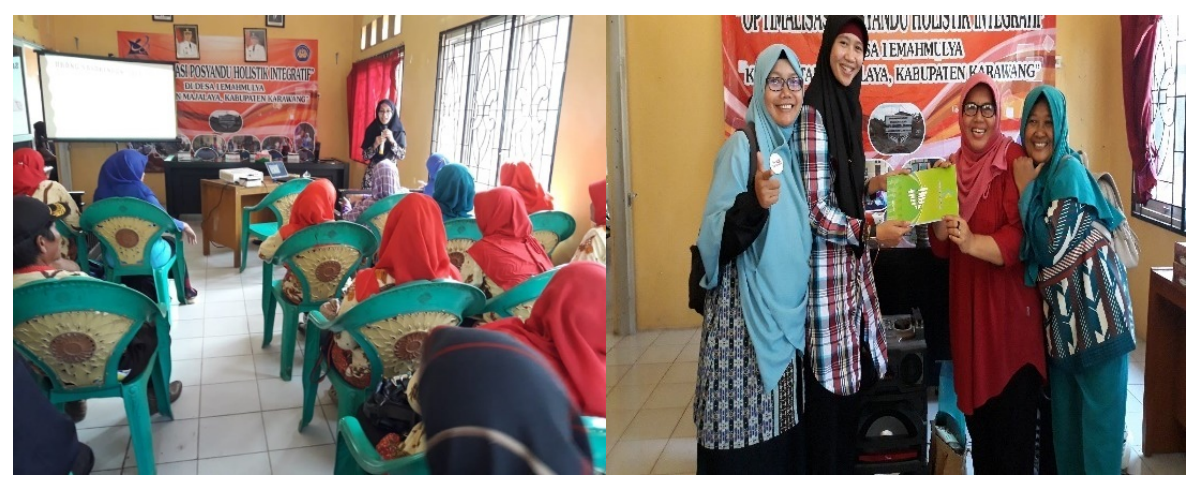

Gambar 6. Pemaparan Materi Stimuliasi Deteksi Dini Perkembangan Balita

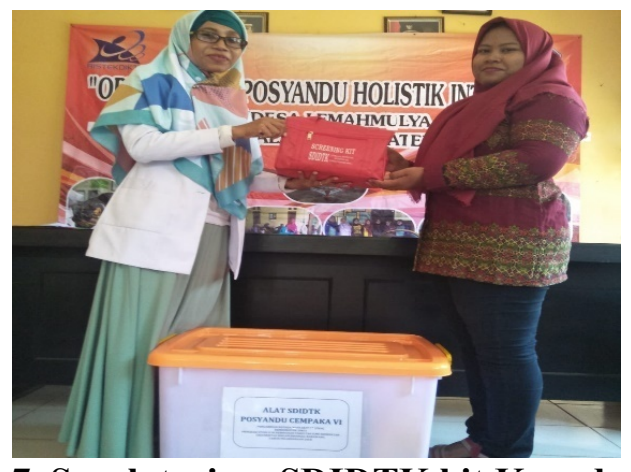

Gambar 7. Serah terima SDIDTK kit Kepada Kader BKB 
JURNAL CEMERLANG: Pengabdian pada Masyarakat ISSN 2654-4741

Vol. 1, No. 1, 2018, $37-57$

DOI: https://doi.org/10.31540/jpm.v1i1.140

5. Pemantauan pertumbuhan bayi balita

Pemantauan pertumbuhan balita dilakukan sesuai dengan usia balita. Pelaksanaan pemantauan pertumbuhan dan deteksi dini kemungkinanan adanya penyimpangan atau gangguan pertumbuhan berdasarkan berat badan dibandingkan tinggi badan pada balita dilakukan setiap 6 bulan, sedangkan pengukuran lingkar kepala setiap 1 tahun. Berbeda dengan anak balita pematauan pertumbuhan pada bayi dilakukan setiap bulan, sedangkan pada anak dibawah 2 tahun setiap 3 bulan. Pemantauan pertumbuhan ini dapat dilakukan oleh kader kesehatan pada pelaksanan kegiatan posyandu.

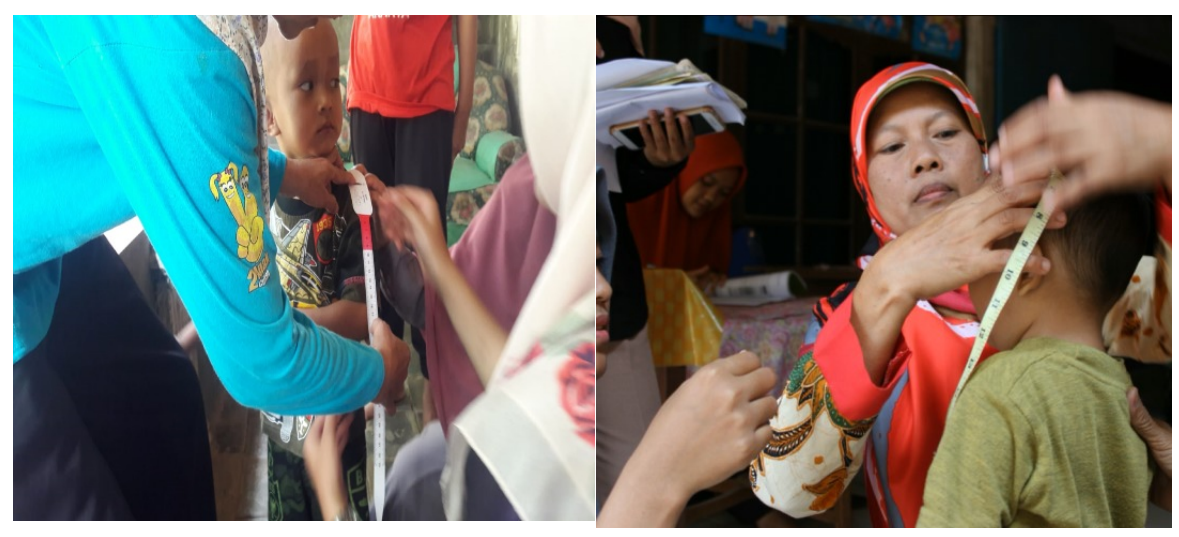

Gambar 8. Kegiatan Pemantauan Pertumbuhan Balita

6. Pemantauan Perkembangan Balita

Pelaksanaan pemantauan perkembangan yang menjadi topik permasalahan dalam kegiatan pengabdian ini, dilakukan dengan kegiatan pemeriksaan / pemantauan perkembangan pada balita di PAUD Imandiri saat pelaksanan kegiatan Posyandu Cempaka VI. Kegiatan ini dilaksanakan oleh guru PAUD dibantu oleh kader BKB, serta melibatkan mahasiswa kebidanan sebagai bagian dari aplikasi matakuliah yang didapat di kampus.

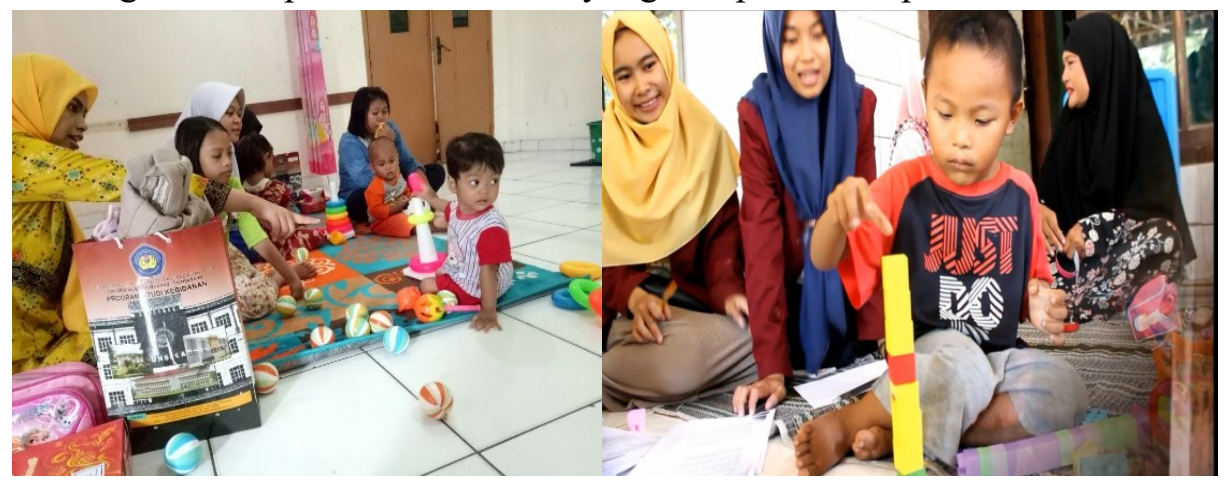

Gambar 9. Pemantauan Perkembangan Balita

https://ojs.stkippgri-lubuklinggau.ac.id/index.php/JPM 
JURNAL CEMERLANG: Pengabdian pada Masyarakat ISSN 2654-4741

Vol. 1, No. 1, 2018, 37 - 57

DOI: https://doi.org/10.31540/jpm.v1i1.140

7. Deteksi pertumbuhan dan perkembangan bayi balita melalui implementasi PAUD Holistik

Pelaksanaan PAUD holistic dengan mengintegrasikan pelayanan posyandu, pelayanan BKB dan PAUD merupakan salah satuupaya untuk dapat meningkatkan derajat pendidikan dan kesehatan serta pelayanan kesehatan bagi sebagai generasi penerus bangsa.

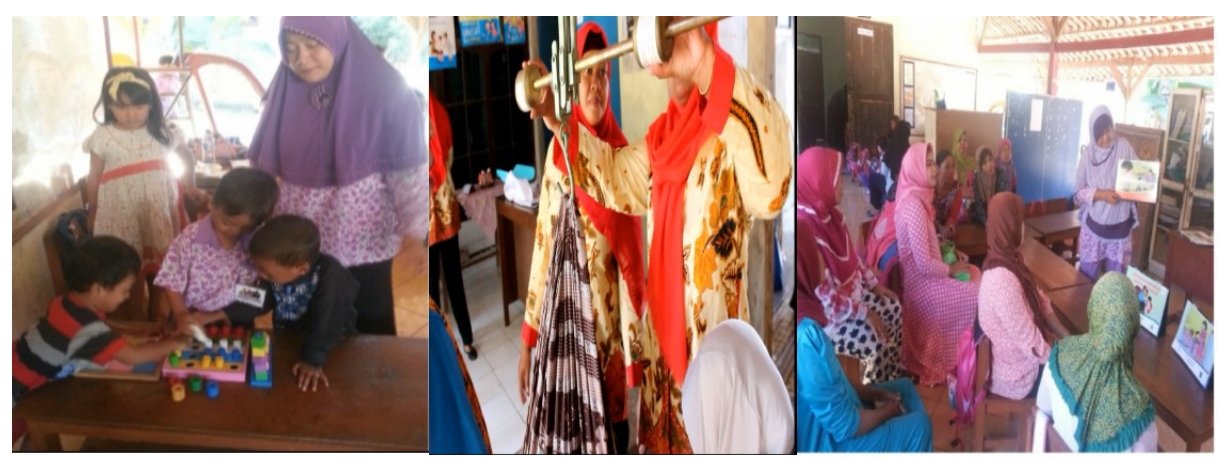

Gambar 10. Implementasi PAUD Holistik

\section{PEMBAHASAN}

Kegiatan pengabdian masyarakat ini bertujuan untuk mengoptimalkan pelayanan PAUD secara holistik didesa Lemahmulya Kecamatan Majalaya Kabupaten karawang. Berikut pembahasan hasil kegiatan PkM :

Kegiatan pengabdian kepada masyarakat ini diawali dengan permohonan izin kepada pemangku kebijakandilanjutkan dengan sosialisasi rencana kegiatan program. Terselenggaranya sosialisasi program dengan pihak terkait tujuan dari permohonan izin. Sosialisasi rencana kegiatan suatu program sangat penting dan sangat diperlukanuntuk menjelaskan maksud dan tujuan dari kegiatan yang akan dilakukan kepada sasaran, agar kegiatan dapat berjalan lancar. Selain itu sasaran kegiatan atau masyarakat setempat dapat ikut berpartisipasi aktif selama kegiatan berlangsung.

Terbentuknya struktur kepanitiaan kader BKB pada mitra melalui Surat Keputusan kepala desa. Dengan adanya SK kepala desa merupakan bentuk 


\section{JURNAL CEMERLANG: Pengabdian pada Masyarakat}

\section{ISSN 2654-4741}

Vol. 1, No. 1, 2018, $37-57$

DOI: https://doi.org/10.31540/jpm.v1i1.140

legalitas bahwa setiap pihak yang terdapat didalam SK tersebut memiliki tanggung jawab untuk melaksanakan tugas dan tanggungjawabnya.

Metode partisipatif melalui permohonan izin dan sosialisasi serta pembentukan kelompok BKB merupakan dukungan kepala desa dan tokoh masyarakat Desa Lemahmulya. Metode ini sejalan dengan hasil penelitian kualitatif yang dilakukan oleh Sihombing, dkk yang menyatakan bahwa dukungan dan motivasi dalam bentuk apapun dari pemangku kebijakan baik kelapa desa, petugas kesehatan maupun kader berdampak pada cakupan D/S yang tinggi pada posyandu di kota Jambi (Sihombing, dkk, 2015)

Metode partisipatif selanjutnya berupa diskusi melalui penyelenggaraan pelatihan/ refreshing bagi guru PAUD, kader posyandu dan BKBtentang SDIDTK. Hal ini dilakukan agar dapat membantu para kader dan guru PAUD untuk lebih memahami materi materi tentang SDIDTK karena bentuk penyampaianya adalah dengan mengulang beberapa yag telah tersampaikan dan memberikan pelatihan berupa materi baru dan praktikum seputar SDIDTK. Metode ini sejalan dengan penelitian Hidayati yang menyatakan bahwa terselenggaranya PAUD Holistik RA melalui program pembelajaran, pelayanan pendidikan, pelayanan kesehatan, gizi seimbang serta pengasuhan anak (Hidayati,U. 2017).

Setelah diberikan beberapa pelatihan mulai dari konsep tumbuh kembang sampai dengan mempraktikan cara mengidentifikasi masalah tumbang dengan menggunakan SDIDTK kit, terdapat peningkatan pengetahuan dan keterampilan tentang tumbuh kembang balita.Peningkatan pengetahuan dan keterampilan para kader dan guru PAUD sebagai bagian dari masyarakat, tentang tumbuh kembang serta SDIDTK di tingkat pelayanan dasar dari 35\% menjadi $80 \%$. Peningkatan pengetahuan ini sejalan dengan pengabdian yang dilakukan Alfiyanti D, dkk tentang optimalisasi kualitas balita dan Yuliani I tentang pelatihan SDIDTK bagi guru PAUD dan wali murid PAUD yang menyatakan bahwa pemantauan tumbuh kembang balita yang telah dilaksanakan masih belum optimal serta kurangnya pengetahuan masayarakat terutama ibu tentang pengasuhan bayi balita. Hasil 


\section{JURNAL CEMERLANG: Pengabdian pada Masyarakat}

ISSN 2654-4741

Vol. 1, No. 1, 2018, $37-57$

DOI: https://doi.org/10.31540/jpm.v1i1.140

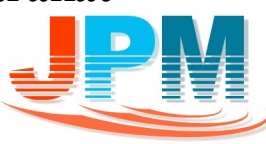

menunjukkan dengan metode pendekatan pelatihan terdapat peningkatan pengetahuan dan keterampilan kader tentang SDIDTK (Alfiyanti D, 2014 dan Yuliani I, 2018)

Permasalahan lain selain kurangnya pengetahuan dan keterampilan dari kader dan guru PAUD adalah tidak tersedianya alat deteksi tumbang secara lengkap mulai dari fase 0-6 tahun lebih khususnya bagi usia $<2$ tahun, maka pada kegiatan pengabdian ini juga memberikan investasi SDIDTK kit bagi mitra untuk menunjang kegiatan deteksi tumbuh kembang dalam program optimalisasi PAUD holistik tidak akan terhambat. Fasilitas Alat Permainan Edukatif (APE) sebagai sarana penunjang dalam kegiatan pengabdian ini sesuai dengan laporan hasil pengabdian yang dilakukan oleh Alfiyanti dkk mengenai Taman pintar Banana sebagai upaya Optimalisasi Kualitas Balita Desa Rowosari Kecamatan Tembalang Kabupaten Semarang yang melatih para kader untuk melakukan stimulasi perkembangan balita dengan menggunakan APE (Alfiyanti, dkk, 2014)

Kelompok sasaran para kader baik guru PAUD, kader kesehatan dan kader BKB telah bergabung untuk dapat memberikan pelayanan PAUD terintegrasi kepada balita di wilayah kerjanya secara bertahap. Pembekalan kader melalui pelatihan yang diberikan berdampak terselenggaranya pelayanan PAUD holistik. Hal ini sejalan dengan penelitian yang dilakukan oleh Cahyadi dkk dengan hasil peningkatan kompetensi kader BKB dalam memberikan pelayanan PAUD holistik integratif (Cahyadi, dkk, 2015)

Pendekatan yang holistik mempunyai beberapa karakteristik, diantaranya : (1) memberikan pelayanan yang komprehensif meliputi stimulasi pada bayi dan anak, pendidikan orang tua, pendidikan secara dini yang dilakukan di rumah dan di pusat-pusat pelayanan pendidikan dan pelayanan kesehatan dan gizi, penyediaan sanitasi yang baik dan sehat, (2) pada tingkat komunitas, berbagai institusi yang menyediakan layanan-layanan tersebut perlu saling mendukung dan menguatkan, (3) memastikan pembinaan yang berkesinambungan. Optimalisasi PAUD holistik ini tentu akan berjalan dengan lancar jika semua pihak yang terkait dapat menjalankan fungsinya dengan baik (Dewi,dkk, 2013) 


\section{JURNAL CEMERLANG: Pengabdian pada Masyarakat}

ISSN 2654-4741

Vol. 1, No. 1, 2018, $37-57$

DOI: https://doi.org/10.31540/jpm.v1i1.140

\section{KESIMPULAN}

Kegiatan pengabdian masyarakat ini berupaya untuk mengoptimalisasikan pelaksanaan PAUD holistik di desa Lemahmulya Kecamatan Majalaya khususnya pada mitra PAUD Imandiri dan Posyandu Cempaka VI. Berikut kesimpulan yang didapat :

1. Terlaksananya sosialisasi program pengabdiankepada masyarakat di desa Lemahmulya Kecamatan Majalaya Kabupaten Karawang.

2. Dukungan positif dari pemerintahan desa dalam pelaksanaan kegiatan program melalui kontribusi yang diberikan.

3. Terbentuknya kader BKB mitra sebagai upaya mewujudkan integrasi posyandu holistik yang disahkan dengan SK kepala desa.

4. Upaya peningkatan pengetahuan keterampilan tentang pertumbuhan dan perkembangan balita melalui refreshing kader dan guru PAUD pada bulan Juli-September, serta peningkatan pengetahuan dan keterampilan tentang tumbuh kembang bayi dan balita sebesar $45 \%$.

5. Investasi SDIDTK kit sebagai menunjangimplementasikegiatan program.

6. Terlaksananya kegiatan pelayanan PAUD holistik di desa Lemahmulya Kecamatan Majalaya Kabupaten Karawang melalui etodemediasi, pelatihan dan investasi APE.

\section{SARAN}

1. Kegiatan pengabdian ini merupakan solusi dari permasalahan yang dihadapi, dengan demikian balita sebagai generasi penerus bangsa dapat terpantau pertumbuhan dan perkembangannya yang akan berdampak pada kehidupan selanjutnya.

2. Kegiatan ini penting dilanjutkan serta perlu peningkatan pelayanan pemantauan pertumbuhan perkembangan dengan adanya kerjasama dan integrasi dari pelayanan baik posyandu, BKB maupun PAUD. Perlunya pemanfaatan prasarana umum desa untuk pelayanan pemantauan 
JURNAL CEMERLANG: Pengabdian pada Masyarakat ISSN 2654-4741

Vol. 1, No. 1, 2018, 37 - 57

DOI: https://doi.org/10.31540/jpm.v1i1.140

pengembangan anak usia dini holistik dan terintegratif. Penambahan APE dengan memberdayakan kreatifitas masyarakat dan memanfaatkan kekayaan lokal.

7. Perlu adanya pembinaan intensif bagi para kader agar pelaksanaan kegiatan PAUD holistik dapat terlaksana secara berkelanjutan.

\section{DAFTAR PUSTAKA}

Alfiyanti D, Maryam, Rahayu, DA, IbM Taman Pintar Banana sebagai Upaya Optimalisasi Kualitas Balita Desa Rowosari Kecamatan Tembalang Kabupaten Semarang. Prosiding Seminar Hasil Penelitian dan Pengabdian, Jurnal Unimus, 2014.

Cahyadi, C, Muthi', A, Hestikasari, Jayanto, AH, Rudianto, E. (2015) Complete Training : Optimalisasi Program PaudHolistic Integratifpada Kader Bina Keluarga Balita (BKB) di Desa Jetu Kelurahan Tegal Gede Kecamatan Karanganyar Kabupaten Karanganyar. PkM Unisula.

Dewi AC, Zahraini DA, Sabarini S. (2013). Desain Pengembangan Anak Usia Dini Holistik Integratif PAUD Non Formal. Jurnal Penelitian PAUDIA. 102-125.

Hidayati U, (2017). Pendidikan Holistik Integratif di Roudhotul Athfal.Jurnal Penelitian Pendidikan Agama dan Keagamaan. Jurnal Pendidikan Agama dan Keagamaan, 2017, 241-262

Kementerian Kesehatan RI, (2016) . Pedoman Pelaksanaan Stimulasi, Deteksi dan Intervensi Dini Tumbuh Kembang Anak Di Tingkat Pelayanan Kesehatan Dasar, Jakarta.

Kementerian Kesehatan bekerjasama dengan Pokjanal, (2011). Pedoman Umum Pengelolaan Posyandu. Jakarta. Kemenkes RI.

https://ojs.stkippgri-lubuklinggau.ac.id/index.php/JPM 
JURNAL CEMERLANG: Pengabdian pada Masyarakat ISSN 2654-4741

Vol. 1, No. 1, 2018, 37 - 57

DOI: https://doi.org/10.31540/jpm.v1i1.140

Septiani, N. (2008) Implementasi Kebijakan Revitalisasi Posyandu di Kabupaten Bekasi, Administrasi dan Kebijakan Kesehatan, Jakarta, Universitas Indonesia

Sihombing K, Kandarina I, Sumarni, 2015, Peran Lurah, Petugas Kesehatan dan Kader dalam Partisipasi Ibu Balita ke Posyandu di Wilayah Cakupan D/S Terendah dan Tertinggi di Kota Jambi, Jurnal Gizi dan Dietetika Indonesia. Vol 3 No 2 (87-97)

Sukesi, N., Rina, D. \& Emilia, K., (2011). Tumbuh Kembang Anak di Posyandu Program Stimulasi, Deteksi dan Intervensi Dini Tumbuh Kembang (SDIDTK).

Suprapto, SP, 2012. Sistem Pembelajaran dalam keterpaduan program Bina Keluarga Balita, Pendidikan Usia Dini dan Posyandu. Jurnal Pendidikan dan Pembelajaran. Volume 19, No 1. 2012

Yuliani I, 2018. Pelatihan Stimulasi Deteksi Intervensi Dini Tumbuh Kembang (SDIDTK) bagi para guru dan wali murid PAUD pada PAUD Baitunnur Gentan Sinduharjo Ngaglik Sleman. Jurnal Pengabdian Dharma Bhakti Volume 1 No 1.

https://ojs.stkippgri-lubuklinggau.ac.id/index.php/JPM 